\title{
Placing the Marginalized Ahmadiyya in Context with the Traditional Sunni Majority
}

\author{
ALEXA BRAND \\ George Mason University
}

\begin{abstract}
This essay describes the Ahmadiyya, a persecuted minority group within Islam, according to the writings of their founder, Hadhrat Mirza Ghulam Ahmad. The Ahmadi differ from traditional Sunni Islam in three major ways: their interpretations of jihad, the person- and prophethood of Jesus Christ, and their understandings of Muhammad as the Final Prophet, which has led to accusations of apostasy. Accordingly, this essay compares and contrasts Ahmadi interpretations with both Qur'anic and Biblical texts in order to accurately describe where it is the Ahmadi community fits on a globalized scale. Largely ostracized due to their interpretative variances with the larger Sunni community, this essay argues that the Ahmadi have a place within the Muslim community, as their similarities far outweigh their differences.
\end{abstract}

\section{Introduction}

Hadhrat Mirza Ghulam Ahmad, founder of the Jama'at-i Ahmadiyya community found largely in Pakistan, is, arguably, one of the most controversial leaders in Islam. Born in 1835, he is largely seen as an apostate by mainstream Islam. Ahmad "claimed to be a muhaddath, someone to whom God speaks; a mujaddid, a renewer of Islam; the Mahdi, a figure known as the guided one who will return in the latter days; and the masih-i maw'ud or the promised messiah widely regarded as the second coming of Jesus."1 Those who follow Ahmad's teachings-known as the Ahmadiyya-believe he was specifically chosen by God as both the messiah and the Mahdi. ${ }^{2}$ The author of over ninety religious books and pamphlets, Ahmad's works are vast. His

\footnotetext{
${ }^{1}$ Adil Hussain Khan, From Sufism to Ahmadiyya: A Muslim Minority Movement in South Asia, (Bloomington and Indianapolis: Indiana University Press, 2015), 6.

2 Hadhrat Mirza Ghulam Ahmad, Invitation to Ahmadiyyat (The London Mosque, 1980) accessed 11/1/2015, https://alislam.org/books/invitation/index.html, part 1, section 5.
} 
writing style tends to follow a "stream of consciousness," but he supported his arguments with references to both the Qur'an and the Bible. While against the traditional norm, the influence of his writing is seen in the millions of Muslims who adhere to his theology. However, the consequences of Ahmad's writings have been multifold.

The accusation of being an apostate in a self-identified Muslim country is rife with consequences and dangers. However, little literature has been produced about the Ahmadi community from within. Largely marginalized, many Ahmadi stay quiet regarding their identities and beliefs. In order to shed light on a growing global phenomenon of inter-Muslim persecution, this paper seeks to identify and dissect the ways in which the Ahmadi interpret Qur'anic and Biblical text and to compare and contrast this with traditional Sunni thought. The analysis in this paper indicates that the Ahmadi, while having different interpretations of Qur'anic text, adhere to basic Islamic principles and values set forth by the Qur'an

The scope of this paper explores the differences between the Ahmadiyya and traditional Sunni in three categories. The first of these categories relates to the matter of jihad. Hadhrat Mirza Ghulam Ahmad proclaimed that jihad is only acceptable if it is non-violent, also known as "the greater jihad." 3 The second category explores the interpretation of Jesus Christ. Ahmad denied Jesus' death on the cross, resurrection, ascent to heaven, and messianic claims. The third and perhaps most controversial category that sets the Ahmadi apart from traditional Sunni followers is that the Ahmadiyya do not believe Muhammad is the Seal of the Prophets and claim that Ahmad is, in fact, not only a prophet, but the long-awaited Messiah and Mahdi.

The Ahmadiyya community has faced considerable amounts of prejudice and persecution from mainstream and traditional Muslims. Since the founding of Pakistan, Ahmadis have been accused of apostasy and systematically blamed for Pakistan's economic perils. In 1953, leader of the prominent political Islamist party Jamaat-e-Islami, Syed Abul A'la Maududi published The Ahmadi Problem, a pamphlet that sought to ostracize, outcast and alienate those who adhere to Ahmad's teaching. ${ }^{4}$ Hundreds of Ahmadi lives were lost due to the slanderous writings, and the violence did not stop. The presence of anti-Ahmadi sentiment has increased tremendously in

\footnotetext{
3 Ibid.

${ }^{4}$ Haroon K. Ullah, Vying for Allah's Vote: Understanding Islamic Parties, Political Violence and Extremism in Pakistan (Washington D.C.: Georgetown University Press, 2014), 22.
} 
Pakistan. This has led to a tragic series of massacres and systematic violence, most notably the slaughter of two thousand Ahmadis in 1953. ${ }^{5}$ In 1974, the Pakistan People's Party (PPP) won a long-considered vote to label the Ahmadiyya as "non-Muslim," which also ensured their inaccessibility to political office or eliminated their equal rights under Pakistani law. ${ }^{6}$ By the 1980s, the Ahmadi faith was considered a "blasphemous" crime punishable by death because of the Hudood Ordinances, issued during military ruler Zia al-Huq's regime. ${ }^{7}$ The current political and social climate in Pakistan has remained contentious, as Ahmadis are banned from referring to themselves as Muslim and cannot engage in traditional practices, including "using Islamic greetings, calling their places of worship mosques, or participating in the Hajj," as any violation of these laws carries a hefty fine and prison time. ${ }^{8}$ Due to governmental and societal pressure and persecution, many Ahmadi have fled Pakistan, as their rights are little to none in their home country.

\section{Interpretations of Jihad}

"And fight in the cause of Allah against those who fight against you, but do not transgress. Surely, Allah loves not the transgressors." "9

The first topic that differs from traditional Sunni interpretations is that of jihad. Although the Ahmadiyya community does not completely deny or reject jihad, violent jihad is almost ubiquitously condemned. According to Ahmad, the use of violent jihad had been a stain on the Muslim community as it "has been described in such a way as to repel people and to prejudice their minds against [Muhammad]. ${ }^{, 10}$ To Ahmad, the only time the Qur'an permitted jihad was to protect places of worship:

Those who have been attacked are permitted to take up arms because they have been wronged... If God did not repel some people by means of others, many monasteries, churches,

\footnotetext{
5 Ibid.

${ }^{6}$ Ibid.

${ }^{7}$ Daud Khattak and Frud Bezhan, "Pakistan's Ahmadis Face Rising Persecution, Violence," Radio Free Europe, Radio Liberty, May 21, 2013, accessed November 5, 2015, http://www.rferl.org/content/pakistan-ahmadispersecution-violence/24992861.html.

${ }^{8}$ Khattak and Bezhan, "Pakistan's Ahmadis Face Rising Persecution, Violence."

${ }^{9}$ Qur'an 2:190

${ }^{10}$ Ahmad, Invitation to Ahmadiyyat, part 1, section 19.
} 
synagogues, and mosques, where God's name is much invoked, would have been destroyed. ${ }^{11}$

Similarly, Qur'an 2:256 states "there is no compulsion in religion." Ahmadi used this verse to argue it is wrong "to think that Islam teaches the use of the sword for the conversion of nonMuslims."12 Rather, Qur'an 25:52 explicitly states to "strive against" the disbelievers by using the Qur'an, not the sword. To Ahmad, jihad via the Qur'an (or jihad of the pen) is the highest and purest form.

The concept of violent jihad, to Ahmad, was no longer applicable in modern terms. Ahmad concluded his argument on the topic by explaining that, while during his migration to Medina, Muhammad faced tribulation, attack and persecution by his enemies and those who wished to thwart his journey. However, only when his enemies tried to "annihilate Islam" were "Muslims given the permission to fight in self-defense."13 Ahmad explained the only accepted reason for jihad was for defending religions facing persecution or annihilation, and in the modern world, it is no longer necessary as the modern world permits religious plurality.

In an age where jihad has become somewhat of a buzzword, most Muslims would agree that violent jihad is outdated, problematic and tarnishes the reputation of Islam. The interpretation regarding the personhood of Jesus provides more of a contrast between the Ahmadi and majority Sunni.

\section{Jesus: Crucifixion, Resurrection, Ascension and the Messiah}

The second difference between Ahmadiyya and traditional Sunni Islam is the interpretation of Jesus, his crucifixion, resurrection and ascension to heaven. According to Ahmadi, Jesus, contrary to what both Christians and other Muslims believe, died a natural death "at the age of 120 years at Srinagar, Kashmir" where his tomb is still located. ${ }^{14}$ Ahmad based this conclusion on eight points of evidence: (1) Biblical evidence (primarily the Gospels); (2) Qur'anic text; (3) medical literature; (4) historical records and accounts; (5) oral tradition that has survived generations; (6) "miscellaneous evidence"; (7) "logical argument" and (8)

\footnotetext{
11 Qur'an 22:39-40

12 Ibid.

${ }^{13}$ Ahmad, Invitation to Ahmadiyyat, part 1, section 19.

${ }^{14}$ Hadhrat Mirza Ghulam Ahmad, Jesus in India (Surrey, UK: Islam International Publications, 1908) accessed 11/3/2015, http://www.alislam.org/library/books/jesus-in-india/index.html, introduction.
} 
revelation from God. ${ }^{15}$ While the location of Jesus' death is significant (particularly considering Ahmad is Pakistani, and Kashmir has been the location of long-held contention), the scope of this paper only seeks to discuss Jesus' crucifixion and ascension by using text from the Qur'an and the Bible, as well as Ahmad's interpretation of both.

\section{Jesus' Crucifixion}

Ahmad first sought to prove that Jesus did not die from crucifixion by relying on his interpretation of Biblical accounts. According to his understanding, Jesus "did not hang on the cross long enough to die from crucifixion," as he was nailed to the cross on a Friday afternoon and it was "Jewish custom to remove the crucified bodies before the Sabbath, which begins at sunset." ${ }^{\text {"16 }}$ Because it was the beginning of the Sabbath, Ahmad wrote that "he remained on the cross only for about two hours" and, nearing the Sabbath, the Jews were acting quickly to remove Jesus from the cross to avoid punishment. ${ }^{17}$

In three of the four Gospels of the Bible, it is recorded that Jesus was hung on the cross around twelve o'clock in the afternoon and died somewhere around three o'clock in the afternoon (see Matthew 27:45-46, Mark 15:33-34 and Luke 23:44). The time Jesus was on the cross varies considerably between the Ahmadiyya interpretation and the Biblical account: if the Jews were attempting to remove all people from the crosses before sundown, Jesus could have stayed on the cross for up to six hours or more (considering he was hung at noon, and could have been removed close to sundown).

But, according to Ahmad, Jesus hung on the cross for only a few hours so there was simply not enough time for him to die as "death by crucifixion involves a process which could have easily been drawn out for several days, if not longer." ${ }^{\prime 18}$ Additionally, according to practice, most of those who were crucified had their legs broken to accelerate their deaths. However, Jesus' legs were, in fact, not broken:

So the soldiers came and broke the legs of the first and then of the other one who was crucified with Jesus. But when they came to

\footnotetext{
${ }^{15}$ Ahmad, Jesus in India, introduction.

16 Adil Hussain Khan. From Sufism to Ahmadiyya: A Muslim Minority Movement in South Asia, (Bloomington and Indianapolis: Indiana University Press, 2015), 45.

${ }^{17}$ Ahmad, Jesus in India, chap. 2.

${ }^{18}$ Khan, From Sufism to Ahmadiyya, 45.
} 
Jesus and saw that he was already dead, they did not break his legs, but one soldier thrust his lance into his side, and immediately blood and water flowed out. ${ }^{19}$

In this passage, there are two main points that Ahmad sought to clarify. First, is the phrase in verse 33: "he was already dead." Because of the emotional and physical torture Jesus underwent prior and during his crucifixion, Ahmad supposes that Jesus fell into "an unconscious state," causing Jesus to appear to be dead to others. ${ }^{20}$

Second, the latter part of verse 34 reads, "immediately blood and water flowed out." Ahmad used this as proof that Jesus was still alive since "dead bodies would not bleed profusely when stabbed once the heart had stopped beating. Instead, blood begins to congeal, which prevents it from rushing forth." ${ }^{21}$ Ahmad claimed that Jesus was on the cross for just two hours, and utilized blood-flow as proof that Christ was not dead. However, there is a possibility that, due to the brief amount of time between Jesus' death and subsequent removal from the cross, his blood had not yet congealed-a possibility Ahmad vehemently denied. Additionally, Ahmad used Mark 15:42-44 as further proof that Jesus was still alive:

Joseph of Arimathea, a distinguished member of the council, who was himself awaiting the kingdom of God, came and courageously went to Pilate and asked for the body of Jesus. Pilate was amazed that he was already dead. He summoned the centurion and asked him if Jesus had already died.

Ahmad believed this is proof that Jesus' death was approached with suspicion and, in fact, both Joseph of Arimathea and Pilate (who Ahmadi described as a God-fearing man) were a part of the conspiracy to take and hide Jesus from the Jews who wanted him dead. ${ }^{22}$

Perhaps the most emotional Biblical text Ahmad used in an attempt to convince his audience that Jesus did not die from crucifixion was the scene of Jesus praying to God in the Garden of Gethsemane. In Luke 22:44, Jesus was so agonized about his impending death that, in the midst of his prayers, his sweat began to fall as drops of blood. Ahmad refused to accept that God, in his infinite power, ignored these prayers and allowed Jesus to die, especially since "Jesus

\footnotetext{
19 John 19:32-34 NAB

${ }^{20}$ Khan, From Sufism to Ahmadiyya, 45.

21 Ibid.

${ }^{22}$ Ahmad, Jesus in India, chap. 2.
} 
himself announced that his Father in heaven listened to his prayers."23 Further, when Jesus cried on the cross, "my God, my God, why have you forsaken me?" (Matthew 27:46), Ahmad believed this cry was made in surprise, as Jesus had fully believed that God would save him from his demise. He additionally questioned the "adverse effect [the crucifixion] would have had on his disciples who had seen with their own eyes that the prayer of a great prophet like Jesus, addressed all night long with such burning passion, had not been accepted."24

\section{Jesus' Resurrection}

Ahmad also denied Jesus' resurrection, which is the most important tenet of the Christian faith. When attempting to dispute the resurrection, Ahmad asked his audience to consider why Jesus appeared "bear[ing] on his hands and feet fresh nail wounds which bled and hurt" and was "prone to hunger and thirst." ${ }^{25}$ Ahmad claimed this indicates Jesus was still in his mortal body. By being in a coma, Jesus did awaken from the tomb, but because he had not died during crucifixion, he had therefore not arisen with a new spiritual body and was still susceptible to the human influences of sleep, hunger and pain. The majority of Sunni Muslims would not argue with Ahmad regarding Jesus' death or resurrection (as they believe Jesus was not on the cross at all). However, they do believe that Jesus ascended directly to heaven, something the Ahmadiyya deny.

\section{Jesus' Ascension to Heaven}

Mainstream Islam teaches that Jesus did not die on the cross (Qur'an 4:157: "They did not kill [Jesus], nor did they crucify him, though it was made to appear like that to them"). But mainstream Islam asserts that Jesus ascended directly to heaven, as stated by the Qur'an in sura 4:158, "God raised [Jesus] up to Himself."

However, the Ahmadi interpret the word "رفع" (raf'a) (raised) in Qur'an 4:158 as "exalted." ${ }^{26}$ By using this word, Ahmad claims that Jesus "was only raised in spiritual status and not raised physically" [emphasis added]. ${ }^{27}$ According to the Ahmadiyya tradition, direct ascent to heaven is impossible because the Prophet Muhammad died. The Ahmadi believe that

\footnotetext{
23 Ibid.

24 Ibid.

25 Ibid.

${ }^{26}$ Khan, From Sufism to Ahmadiyya, 46.

27 Ibid.
} 
Muhammad was a greater prophet and more beloved by God than Jesus, therefore, it cannot be that Muhammad would die a "normal death" yet Jesus would be granted ascension. ${ }^{28}$ Jesus' ascension is further challenged as it assumes Jesus has god-like powers. Assigning god-like powers or describing someone as "equal" in any way to God is stridently opposed in Sunni Islam. If Jesus had these powers, it is incongruous with the Islamic concept of tawhid (the oneness of God).

Additionally, according to Ahmad, when the Prophet Muhammad died, the whole community of the Prophet was in mourning. ${ }^{29}{ }^{30}$ To Ahmad, this proved that "all prophets before the Holy Prophet had died. There was no exception... [otherwise] they could have said that at least Jesus had been alive." 31 There was no hesitation of whether or not Muhammad was really dead, as there had been no other prophet before him who had been resurrected; there was no precedent that proved ascension was possible.

\section{Jesus as the Messiah}

According to both traditional Islamic and Christian thought, Jesus will come again as the Messiah to destroy the anti-Christ (al-Dajjal). In Islam specifically, Jesus will arrive with the assistance of the Mahdi, who will come to unite the Islamic community and bring the world to justice. But, according to Ahmad, since Jesus is dead, he is not somewhere waiting to return. Therefore, Jesus cannot come "again" and "the promised one can only be a follower of the Holy Prophet, not the Messiah of Nazareth who died in the normal way." 32 Further, Ahmad argued that there is "no need to resuscitate the Messiah of Nazareth" because God is all-powerful and "can raise a teacher from among the followers of the Holy Prophet, install him as the Promised Messiah and charge him with the duty of reforming the world." 33 There is no other instance in the Bible of a prophet being "re-used," therefore, God would have no need to recycle Jesus. ${ }^{34}$ Although the Qur'an explicitly states that Jesus will return, Ahmad said this was done metaphorically as "Jesus devoted his life to the service of truth and goodness; so will the

\footnotetext{
${ }^{28}$ Ahmad, Invitation to Ahmadiyyat, part 1, section 6.

${ }^{29} \mathrm{Ahmad}$, Invitation to Ahmadiyyat, part 1, section 6.

${ }^{30}$ Qur'an 39:31

${ }^{31}$ Ahmad. Invitation to Ahmadiyya, part 1, section 8.

32 Ibid.

33 Ibid.

34 Ibid.
} 
Promised One." ${ }^{35}$ Therefore, the Messiah will only need to exhibit the qualities exampled by Jesus, not be Jesus himself.

By following Ahmad's teachings, the Ahmadiyya community has faced extreme persecution and discrimination from the rest of the Sunni Muslim community. Considering he believed Jesus is not the Messiah, Ahmad concluded that the only logical explanation is that he, Hadhrat Mirza Ghulam Ahmad, is both the Mahdi and the Messiah. Although his claim and his consolidation of the Mahdi and Messiah into one person may be confusing to his readers, for the Ahmadi Community it is a matter of faith.

\section{Muhammad and the Seal of Prophethood}

"Certainly, do say he is the Seal of all Prophets, but do not say there is no prophet after him. ${ }^{, 36}$ (Hadith attributed to Ayesha, wife of the Prophet)

Qur'an 33:40 is perhaps one of the most important verses in all of Islam regarding the Prophet Muhammad. It states, "Muhammad is not the father of any one of you men; he is God's Messenger and the seal of the prophets." ${ }^{37}$ Muhammad is largely believed to be "not only inspired in some way, but truly a prophet bringing a revealed scripture... [he was] the final one in a long series of God's revelation."38

Additionally, in Qur'an 5:48, it was explicitly revealed to the Prophet Muhammad that he had "final authority" over the truth of the Scriptures. This verse states, "We sent to you [Muhammad] the Scripture with the truth, confirming the Scriptures that came before it, and with final authority over them." ${ }^{\prime 39}$ The concept of Muhammad being the final prophet is known as "khatam an-nabiyyin" (خاتم النبيين), usually translated as "Seal of the Prophets."

Ahmad argued that sura 33:40 has been mistranslated and misrepresented by the majority of the Muslim community. For instance, Ahmad explained that khatam (خاتم) in the Qur'an is

\footnotetext{
${ }^{35}$ Ahmad. Invitation to Ahmadiyya, part 1, section 8.

${ }^{36}$ Hadith, Takma Majma-ul Bahar, Vol.4, pg. 85.

${ }^{37}$ Qur'an 33:40.

${ }^{38}$ Fred Donner, Muhammad and the Believers: At the Origins of Islam (Cambridge, MA: Harvard University Press, 2010), 76.

${ }^{39}$ Qur'an 5:48
} 
written by using the fatha (the short vowel "a" above the "t"), rather than the kasra (the short vowel " $\mathrm{i}$ " below the " $\mathrm{t}$ "). By using the fatha, the word translates to "seal," by using the kasra (which he believed is a misrepresentation), the word is translated as "the last person." 40 Therefore, the correct spelling of the word is خانَم. This does not necessarily mean that Muhammad was the last Prophet, but, rather, the seal of the prophets. According to Ahmad, the two words could not be more different from one another:

The word khatam denotes the consummation and completion of a thing, which [is] explained by the words, authenticity, perfection and validity. When a seal is put to a letter it becomes authentic and complete. The seal may be put in the end or in the beginning. Khatam an-Nabiyyin would mean the truest and the most perfect of prophets and not the last in point of time. It refers to his status and place among the prophets and not to the time of his advent. ${ }^{41}$

In traditional Sunni thought, Muhammad "ended" the line of prophets sent from God dating to Abraham. However, in the Ahmadiyya community, "the institution of revelation and of the coming of prophets continues after the Holy Prophet" and Muhammad is not the final prophet but some have come after him. ${ }^{42}$ Ahmad argued this is possible as "the doors to spiritual blessings and spiritual progress have not been closed by [Muhammad]. They have instead been thrown wide open." ${ }^{43}$ It is here where Ahmad again paved the way to enter himself as the Messiah, "though he does not bring a new law, does not abrogate any part of an earlier law, and is not free from the obligation to follow an earlier prophet, he may still be a prophet."44 According to his writing and interpretations, Ahmad exhibited all necessary qualities to be a prophet, therefore he must be accepted as such. By self-identifying as a prophet, Ahmad-in the eyes of mainstream Muslims-committed blasphemy. This interpretation is perhaps the most damaging to Ahmadi-Sunni relations, as it is used as proof that Ahmadiyya are not Muslim.

\footnotetext{
${ }^{40}$ Ahmad. Invitation to Ahmadiyya, part 1, section 15.

41 Ibid.

${ }^{42}$ Ahmad. Invitation to Ahmadiyya, part 1, section 15.

43 Ibid.

${ }^{44}$ Ahmad. Invitation to Ahmadiyya, part 1, section 20.
} 


\section{Early Complications: Correction of an Error (1901)}

Due to overwhelming accusations of apostasy, in the early 1900's, Ghulam Ahmad was forced to issue a pamphlet "Correction of an Error" to address a disgruntled populace. He claimed that, while he did not explicitly name himself as a prophet, he did, in fact, exhibit certain qualities of Prophethood. ${ }^{45}$ For instance, he explained that Muhammad-the Seal of the Prophets-does not close all doors to Prophethood, but rather, "all the windows of Prophethood have been closed but one window... namely fana fir-rasul (self-effacement in the Holy Prophet.) ${ }^{\$ 46}$ Self-effacement, to Ahmad, was equal in status to Prophethood, and therefore placed him on a similar level as the Prophet Muhammad.

He also explained his claims by clarifying that Muhammad was the final prophet, but in sharia law only. "After our Holy Prophet Muhammad till the Day of Judgment, there is no Prophet to whom a sharia is to be revealed... whoever makes such a claim commits heresy." By reemphasizing that Muhammad is the last "law-bearing" Prophet, and by invoking his earlier claim that one may still be a prophet (if he does not bring law, abrogate law, or free himself from law), he argued he was not guilty of heresy, and believed his claim deserved validity in Islam.

Additionally, Ahmad invoked the use of language, specifically the two words nabi (prophet [نبي]) and rasul (messenger [رسول]). While both nabi and rasul are largely used in the Qur'an to describe Muhammad, Ahmad asked his criticizers, "as I have received... about 150 prophecies from God, and seen with my own eyes that they were fulfilled clearly, how can I deny the application of the word nabi or rasul to myself?" 48 Again, admitting that Muhammad is the last law-bearing Prophet, Ahmad maintained the words nabi and rasul can be used generically, if one has truly received revelation from God.

Furthermore, by imitating his lifestyle after the Prophet Muhammad (and by adopting fana fir-rasul), he identified himself with Muhammad's "very being and thereby acquired his

\footnotetext{
45 Khan, From Sufism to Ahmadiyya, 52.

${ }^{46}$ Hadhrat Mirza Ghulam Ahmad, Correction of an Error, trans. Ayk Ghalati Ka Izala (UK: Ahmadiyya Anjuman Lahore Publications, 2011), 10-11.

${ }^{47}$ Ahmad, Correction of an Error, 10-11.

${ }^{48}$ Ahmad, Correction of an Error, 13.
} 
own prophetic status." 49 In this sense, because Ghulam Ahmad had "no new scripture to disseminate and no new law to supplement or supersede the sharia, he was not a prophet of God" yet he was only "ascribed Prophethood through his pure and perfect spiritual imitation of Muhammad." ${ }^{, 50}$ Therefore, his claim to Prophethood was substantiated only by his infallible imitation of the Prophet, who was the last of the law-abiding Prophets.

While Ahmad's argument is cyclical and confusing at times, he attempted to save himself from apostasy by ultimately restating that Muhammad was the last Prophet, but adding a caveat. However, by choosing to change the interpretation of the Qur'an (specifically regarding Jesus' ascent and Muhammad's finality in the lineage of prophets), Ahmad has been accused by other Sunnis of being a law-bearing prophet to his followers. However, according to Ahmad and the Adhmadi, the ability to practice ijtihad is also a matter of Qur'anic interpretation.

\section{Placing the Ahmadi in an Islamic Context}

"Goodness does not consist in turning your face towards East or West. The truly good are those who believe in God and the Last Day, in the angels, the Scripture, and the prophets; who give away some of their wealth, however much they cherish it, to their relatives, to orphans, the needy, travelers and beggars, and to liberate those in bondage; those who keep up the prayer and pay the prescribed alms; who keep pledges whenever they make them; who are steadfast in misfortune, adversity and times of danger. These are the ones who are true, and it is they who are aware of God." 51

One effective way to place the Ahmadi community in context is through the Qur'an and its requirements for Muslims. Islam, according to Fred Donner, well-respected professor of Near Eastern History at the University of Chicago, revolves around five central doctrines. The first is to "recognize the oneness of God." "God is one-he has no partner here or in heaven." 53 The second central doctrine is the belief in the Day of Judgment. Ahmad, while not explicitly stating it amongst his twelve main beliefs,

\footnotetext{
${ }^{49}$ Khan, From Sufism to Ahmadiyya, 52.

50 Ibid.

${ }^{51}$ Qur'an 2:177

52 Donner, Muhammad and the Believers, 58.

${ }^{53}$ Ahmad, Invitation to Ahmadiyyat, part 1, section 4.
} 
expanded on the Day of Judgment quite a bit, as he believes himself to be the Messiah and Mahdi. We can therefore infer that the Day of Judgment is also a part of Ahmadiyya doctrine. The third doctrine is that God uses messengers to reach his people. This tenet is also upheld in the Ahmadi community, as they believe Ahmad to be both nabi and rasul. Ahmad also explicitly stated his belief in "Divine Messengers" from God. ${ }^{54}$ Fourth, is the existence of angels. Ahmad agreed that angels exist, as is evidenced by his statement that "we believe angels are a part of God's creation." 55

Lastly, the belief and appreciation of the infallibility of the Qur'an as the literal word of God is central to Islam. Ahmad relied on Qur'anic text in order to prove a number of his theories, although he did not explicitly state his belief in the infallibility of the Qur'an. However, as has been explained above, Ahmad depended heavily on ijtihad, or his own independent reasoning and interpretation of the text. Perhaps the most provocative are his interpretations and definitions of the words خاتم an he deliberately chose the translations that best fit his theories. While this is not contradictory to holding the Qur'an in elevated status, his against-the-grain interpretation has offended the majority of mainstream Muslims.

Additionally, he supplemented many of his beliefs by using hadith, reports of sayings or acts attributed to the Prophet Muhammad. While not considered un-Islamic, hadith are generally less revered in comparison to the Qur'an, and can run into many complications on their own, as they can be unreliable and the variances of hadith number into the thousands. Furthermore, different hadiths exist for different traditions, leading one to wonder whether or not the hadith Ahmad used are accepted by other schools of thought, or just the Ahmadi.

But what does the Qur'an say is required in order to be considered a believer? The first is that Muslims must engage in regular prayer (Qur'an 17:78-79): "this includes both informal prayers requesting God's assistance or invoking His favor ( $d u^{\prime} a$ ') and the more formalized ritual prayer (salat)." ${ }^{56}$ Prayer is performed in all Muslim communities, including the Ahmadi. Second, “another practice that the Qur'an describes as vital for Muslims is charity toward the less

\footnotetext{
54 Ibid.

55 Ahmad, Invitation to Ahmadiyyat, part 1, section 4.

56 Donner, Muhammad and the Believers, 61.
} 
fortunate in life" as stated in Qur'an 2:177. ${ }^{57}$ The Ahmadiyya community has been at the forefront of many humanitarian causes, including founding Humanity First, an international organization that aims to "relieve suffering caused by natural disaster and human conflict, promote peace and understanding based on mutual tolerance and respect, and strengthen people's capacities to help themselves." ${ }^{58}$ This is evidence that the Ahmadi are engaged in acts of charity and piety. Third, is performing the Hajj or pilgrimage as commanded by Qur'an 2:196. While Ahmadis have been accused of not performing Hajj, the majority of Ahmadis in Pakistan are unable to do so because of stipulations enacted by both the Pakistani and Saudi Arabian government who label them as non-Muslim, and therefore, prohibited from partaking in Islamic rituals. ${ }^{59}$ According to the Ahmadiyya Muslim Association, the Ahmadi "are not the only ones who were prevented from doing the Pilgrimage. Our beloved Holy Prophet was also prevented from doing the Pilgrimage by the Quraysh. So if we are in the same company as the Holy Prophet, then what blessed company that is." ${ }^{60}$ Therefore, it can be assumed that, given the opportunity, Ahmadis would embark on the Hajj.

Given the five stipulations required of Muslims by the Qur'an, the Ahmadi comply. The area of most contention, the person of the Prophet Muhammad, is least discussed in the Qur'an above any other topic or category. Although the Prophet Muhammad is considered one of the most influential spiritual leaders of all time, the Qur'an itself says very little about him. Taking this into account, the Ahmadi community adheres to the word of the Qur'an, and that is truly the only text considered infallible by all Muslims.

\section{Conclusion}

The Ahmadiyya have faced extreme amounts of persecution in the Muslim community. While some simply label them as "non-Muslim," others have gone so far as to accuse them of apostasy, perhaps one of the most severe accusations in all of Islam. The government of Pakistan has required all Ahmadi to be barred from participating in Islamic rituals, does not allow them to

\footnotetext{
57 Donner, Muhammad and the Believers, 63.

58 "Our Mission," Humanity First, accessed November 15, 2015.

http://usa.humanityfirst.org/index.php?option=com_content\&task=view\&id=24.

59 "Why do Ahmadis not perform Hajj?," WhyAhmadi, accessed November 10, 2015. http://whyahmadi.org/objections-raised/why-do-ahmadis-not-perform-hajj.html.

60 Ibid.
} 
identify as "Muslim" without severe consequences, and systematic and repressive violence against the Ahmadi is usually ignored or, sometimes, encouraged. ${ }^{61}$

This paper discussed the three largest ways in which Ahmadi differ from the rest of the Sunni community: their interpretations of jihad (in the historical context of which it was first discussed), the denial of Jesus' death, resurrection, ascension and Jesus as the Messiah, and the belief that Muhammad was not the final prophet. However, as distant as the Ahmadiyya's differences may be from classical Sunni interpretations of the Qur'an, the practices the Qur'an explicitly command of Muslims are followed fervently by the Ahmadi. Therefore, in an era of increasing globalization and in the midst of schisms and fractures within the Muslim world, the Ahmadi may have a place within the Muslim community, as their similarities far outweigh their differences.

${ }^{61}$ Ullah. "Vying for Allah's Vote," 22. 


\section{Bibliography}

Ahmad, Hadhrat Mirza Ghulam. Invitation to Ahmadiyyat. London: The London Mosque, 1980. Accessed November 1, 2015. https://alislam.org/books/invitation/index.html

—. Jesus in India. Translated by Masi Hindustan Mein. Surrey, UK: Islam International Publications, 1908.

- Correction of an Error. Translated by Ayk Ghalati Ka Izala. UK: Ahmadiyya Anjuman Lahore Publications, 2011.

Donner, Fred. Muhammad and the Believers: At the Origins of Islam. Cambridge, MA: Harvard University Press, 2010.

Humanity First. “Our Mission.” Accessed November 15, 2015. http://usa.humanityfirst.org/index.php?option=com_content\&task=view\&id=24

Khan, Adil Hussain. From Sufism to Ahmadiyya: A Muslim Minority Movement in South Asia. Bloomington \& Indianapolis: Indiana University Press, 2015.

Khattak, Daud and Frud Bezhan. "Pakistan's Ahmadis Face Rising Persecution, Violence." Radio Free Europe Radio Liberty, May 21, 2013. Accessed November 5, 2015. http://www.rferl.org/content/pakistan-ahmadis-persecution-violence/24992861.html

Ullah, Haroon K. Vying for Allah's Vote: Understanding Islamic Parties, Political Violence and Extremism in Pakistan. Washington, D.C.: Georgetown University Press, 2014.

Why Ahmadi. "Why do Ahmadis not perform Hajj?” Accessed November 10, 2015. http://whyahmadi.org/objections-raised/why-do-ahmadis-not-perform-hajj.html 